\title{
Use of virginiamycin improves performance of high-prolific sows during gestation and lactation over two cycles
}

\author{
Uso de virginiamicina melhora o desempenho de fêmeas suínas de alta prolificidade durante a \\ gestação e lactação em dois ciclos \\ El uso de virginiamicina mejora el rendimiento de cerdas de alta prolificidad durante la gestación y \\ lactancia en dos ciclos
}

Received: 10/16/2021 | Reviewed: 10/23/2021 | Accept: 11/03/2021| Published: 11/05/2021

\author{
Bruno Alexander Nunes Silva \\ ORCID: https://orcid.org/0000-0001-6039-6471 \\ Universidade Federal de Minas Gerais, Brazil \\ E-mail brunosilva@ufmg.br \\ Leonardo David Tuffi Santos \\ ORCID: https://orcid.org/0000-0002-9362-778X \\ Universidade Federal de Minas Gerais, Brazil \\ E-mail: ltuffi@ica.ufmg.br \\ Dante Pazzanese Duarte Lanna \\ ORCID: https://orcid.org/0000-0002-7082-8853 \\ Universidade de São Paulo, Brazil \\ E-mail:dplanna@usp.br \\ Carlos Junior Kippert \\ ORCID: https://orcid.org/0000-0003-4888-491X \\ Phibro Animal Health Corporation, Brazil \\ E-mail: carlos.kippert@brf.com \\ Paulo Henrique Reis Furtado Campos \\ ORCID: https://orcid.org/0000-0002-5031-0790 \\ Universidade Federal de Viçosa, Brazil \\ E-mail: paulo.campos@ufv.br \\ Wagner Azis Garcia Araujo \\ ORCID: https://orcid.org/0000-0002-9106-643X \\ Instituto Federal do Norte de Minas Gerais, Brazil \\ E-mail: aziszoo@yahoo.com.br \\ Kariny Fonseca da Silva \\ ORCID: https://orcid.org/0000-0002-9653-1564 \\ Universidade Federal do Paraná, Brazil \\ E-mail: karinyfonseca23@gmail.com \\ Hysla Milena Cunha Cardoso \\ ORCID: https://orcid.org/0000-0002-9848-7560 \\ Universidade Federal de Lavras, Brazil \\ E-mail:hyslamilena@gmail.com
}

\begin{abstract}
Feed additives can be used as potential strategies to enhance the efficiency of nutrient utilization by the sow can impact on the reduction of feed costs and in addition improve sow and litter health. The objective of this study was to evaluate the impact of the supplementation of virginiamycin (VM) in diets for gestating and lactating sows over two consecutive productive cycles on the animals productive and reproductive performance. Sows that received VM showed a lower BW, body protein and energy losses during both lactations when compared to control sows $(P=$ $0.001)$. VM treatment increased $(+6 \% ; P=0.001)$ piglet weaning weight. The litter daily gain was also influenced $(P$ $=0.001$ ) by the treatments were litters from VM fed sows showed an improved daily gain when compared to control sows $\left(2.61\right.$ vs. $2.24 \mathrm{~kg} \mathrm{~d}^{-1}$ respectively). Average daily milk production improved by $17 \%(P=0.001)$ in the VM sows when compared with the control. Also, an improvement in milk fatty acid profiles were found in sows fed VM. As a conclusion, we can infer that the constant use of VM in the diets of sows during gestation and lactation improves both sow and litter performance.
\end{abstract}

Keywords: Antibiotic; Piglets; Female; Milk production. 


\begin{abstract}
Resumo
Os aditivos alimentares podem ser utilizados como estratégias potenciais na nutrição de fêmeas suínas para aumentar a eficiência de utilização de nutrientes e reduzir os custos de alimentação e, além disso, melhorar a saúde das matrizes e leitegadas. O objetivo deste estudo foi avaliar o impacto da suplementação da virginiamicina (VM) para desempenho produtivo e reprodutivo dos animais em dietas de fêmeas gestantes e lactantes ao longo de dois ciclos produtivos consecutivos. As porcas que receberam virginamicina (VM) apresentaram menor peso corporal (BW), perdas de proteínas corporais e perda de energia em ambas as lactações quando comparadas com as matrizes do grupo controle $(P=0,001)$. O tratamento com VM aumentou $(+6 \% ; P=0,001)$ o peso de desmame de leitões. O ganho diário da leitegada também foi influenciado $(P=0,001)$ pelos tratamentos com VM e o ganho diário foi melhor quando comparado com as fêmeas do controle (2,61 vs. $2,24 \mathrm{~kg} \mathrm{~d}^{-1}$ respectivamente). A produção média diária de leite melhorou em $17 \%(P=0,001)$ nas porcas alimentadas com VM quando comparadas com o controle. Também foi encontrada uma melhoria nos perfis dos ácidos graxos do leite nos animais alimentados com VM. Como conclusão, podemos inferir que o uso constante de VM na dieta das porcas durante a gestação e lactação melhora tanto o desempenho das matrizes como da leitegada.
\end{abstract}

Palavras-chave: Antibiótico; Leitões; Fêmea; Produção de leite.

\title{
Resumen
}

Se pueden utilizar aditivos alimentarios como estratégia funcional en la alimentación de las cerdas para aumentar la eficiência de utilización de los nutrientes y reducir los costes, además, actuan mejorando su salud y la de sus camadas. El objeto de este estúdio fue evaluar el impacto de la suplementación con virginiamicina (VM) sobre el rendimento productivo y reproductivo de los animales em dietas de cerdas gestantes y lactantes a lo largo de dos ciclos productivos consecutivos, Las cerdas que recibieron virginamicina (VM) tuvieron menor peso corporal (PV), pérdida de proteína corporal y pérdida de energía en las dos lactaciones em comparación con las cerdas del grupo control $(P=$ 0,001). Por otro lado, las cerdas com el tratamiento VM aumentaron $(+6 \% ; P=0,001)$ el peso de destete de los lechones de sus camadas. La ganancia diária de la camada también fue afectada $(P=0,001)$ por efecto del tratamento con VM y la ganancia diária fue mayor em comparación con las cerdas del tratamento control $\left(2,61 v s .2,24 \mathrm{~kg} \mathrm{~d}^{-1}\right.$ respectivamente). La producción média diária de leche mejoró en un $17 \%(P=0,001)$ en las cerdas alimentadas con VM en comparación con las del control. También se observó una mejoría en el perfil de ácidos grasos de la leche en los animales alimentados con VM. Como conclusión, podemos deducir que el uso constante de VM en las dietas de cerdas durante la gestación y la lactación mejora tanto el rendimento de las cerdas como el de sus camadas.

Palabras clave: Antibióticos; Lechones; Hembra; Producción de leche.

\section{Introduction}

Nutritional strategies used to improve the performance of sows generally are associated with dietary manipulation. Several nutrients or feed additives that increase performance (i.e., antibiotics), demonstrate an efficient amino acid and energy utilization and therefore offer potentially benefits not only as growth enhancers, but also improve sow performance and longevity. Feeding level, amino acid and energy intake during gestation and lactation represent important indicators of sow performance and have been extensively investigated and well documented by literature (Noblet \& Etienne, 1989; Quiniou \& Noblet, 1999; Kim et al., 2009). Therefore, the interest in feed additives, commonly used as growth promotors in other pig categories (i.e., growing-finishing pigs), is to study their effects on reproductive and productive performance of sows.

Factors that can improve the efficiency of feed utilization by the sow, can contribute to improve feed costs, which represent great proportion of the total production costs in the pig industry, and as a secondary effect improve sow and litter health status (Kyriakis et al., 1992). The use of antibiotics may result in improved economic gains in pigs living in sub-optimal conditions rather than in those reared in the highest welfare and environmental conditions. The establishment of a beneficial intestinal microbiota at birth could lead to healthier pigs, this could be achieved in an effective way by treating sows, which could potentially provide an optimized transfer of beneficial bacterial strains from the sow to the neonatal pigs' environment.

Several results from previous studies investigating the effects of different dietary levels of dietary VM supplementation on sow performance have been published in the past (Kyriakis et al., 1992; Curran et al., 1994; and Monetti et al., 1998). It is of general agreement among these later authors that the best level of inclusion observed, which improved performance traits, was of $40 \mathrm{mg} \mathrm{kg}^{-1}$ or $40 \mathrm{ppm}$. Nevertheless, current sow genotypes are high producing and have a reduced 
voluntary feed intake as a consequence of the genetic selection for higher feed efficiency and therefore are much more susceptible to immunological challenges. The fact that metabolism is affected by genetic selection implies in the need of modified nutritional strategies to reach the current sow's daily needs in order to keep up with the high nutritional demands to maintain productivity. In this sense, the use of VM could improve gut health and sow feed efficiency and therefore allowing piglets to benefit at weaning by improving vitality, survival rates and performance. Therefore, the present study aimed to evaluate the impact of the supplementation of VM in diets for gestating and lactating sows over two consecutive productive cycles on their productive and reproductive performance.

\section{Materials and Methods}

Methods involving animal handling were performed in agreement with the regulations approved by the Institutional Animal Welfare and Ethics/Protection committee from the Universidade Federal de Minas Gerais (UFMG) under the protocol n. 307/2016.

\subsection{Animals and Experimental Procedure}

The study was performed between Dec 2016 and Dec 2017 and was conducted in the facilities of a sow unit commercial farm, located in a tropical climate region in the state of Minas Gerais at a Latitude: $20^{\circ} 43^{\prime} 13^{\prime \prime}$ South and Longitude: $46^{\circ} 36^{\prime} 36^{\prime \prime}$ West.

A total of 160 high-prolific multiparous sows from a commercial genetic line divided from two successive batches of 80 sows each were used in this study. Within each replicate, sows were distributed in a completely randomized experimental design among 2 dietary treatments according to parity order (1st, 2nd, 3rd to 4th, $>5$ th parity), body weight and backfat thickness $24 \mathrm{~h}$ after insemination. The sows were distributed to one of the two treatments represented by a control diet and an experimental diet with an inclusion of $40 \mathrm{ppm}$ of virginiamycin (Staffac ${ }^{\circledR}$ ) during the gestation and lactation phases (Table 1). Each treatment consisted of 80 repetitions, being each sow considered as an experimental unit. The sows remained in the experiment during two complete reproductive cycles, starting from $\mathrm{d} 1$ post insemination until next cycle insemination.

The sows were housed individually in gestating crates until $110 \mathrm{~d}$ of gestation. On d 110 of gestation, sows were washed and transferred to the lactation unit and housed in individual farrowing pens $(2.1 \times 2.2 \mathrm{~m})$ on a slatted plastic floor and fed $2 \mathrm{~kg} \mathrm{~d}^{-1}$ of the control or test lactation diet (Table 1) until the day of farrowing. Twenty-four hours after farrowing, the sows had their body weight and backfat thickness was measured. After farrowing, the sows were submitted to a step-up feeding program to stimulate a gradual feed intake increase up to day 7 post-farrowing. Initially sows were allowed $2 \mathrm{~kg}$ on day 1 post-farrowing and reached $8 \mathrm{~kg} \mathrm{~d}^{-1}$ on day 7 . The allowance increased by $1 \mathrm{~kg}$ each day. The sows were fed following this feeding management to avoid over-consumption at the beginning of lactation and possible agalactia problems. After $\mathrm{d} 7$ sows were allowed feed ad libitum and had free access to water via water nipples throughout all the experimental period. 
Table 1 - Composition of the experimental diets.

\begin{tabular}{|c|c|c|c|c|}
\hline \multirow{3}{*}{ Ingredients } & \multicolumn{2}{|c|}{ Gestation } & \multicolumn{2}{|c|}{ Lactation } \\
\hline & T1 & $\mathrm{T} 2$ & $\mathrm{~T} 1$ & $\mathrm{~T} 2$ \\
\hline & $0.0 \% \mathrm{VM}^{* *}$ & 40 ppm VM & $0.0 \% \mathrm{VM}$ & $40 \mathrm{ppm} \mathrm{VM}$ \\
\hline Corn $(7.8 \%)$ & 566.82 & 566.78 & 671.26 & 671.22 \\
\hline Soybean meal (45\%) & 205.00 & 205.00 & 250.00 & 250.00 \\
\hline Soybean oil & - & - & 40.40 & 42.80 \\
\hline Wheat middlings & 200.00 & 200.00 & - & - \\
\hline Dicalcium phosphate & 8.28 & 8.28 & 15.00 & 15.00 \\
\hline Limestone $(36 \%)$ & 13.05 & 13.05 & 9.50 & 9.50 \\
\hline Salt & 4.55 & 4.55 & 4.99 & 4.99 \\
\hline Virginiamycin & 0.00 & 0.08 & 0.00 & 0.08 \\
\hline L-Lysine HCL & - & - & 3.01 & 3.02 \\
\hline DL-Methionine & - & - & 0.46 & 0.48 \\
\hline L-Threonine & - & - & 1.08 & 1.10 \\
\hline L-Tryptophan & - & - & 0.30 & 0.31 \\
\hline Premix Mineral/Vitamin* & 2.30 & 2.30 & 4.00 & 4.00 \\
\hline Total & $1,000.00$ & $1,000.00$ & $1,000.00$ & $1,000.00$ \\
\hline Analysed composition & & & & \\
\hline $\mathrm{CP}(\%)$ & 16.44 & 16.54 & 16.82 & 16.85 \\
\hline $\mathrm{CF}(\%)$ & 4.33 & 4.31 & 2.86 & 2.82 \\
\hline $\mathrm{ME}(\mathrm{Mcal} / \mathrm{kg})$ & 2.95 & 2.95 & 3.40 & 3.40 \\
\hline Calcium (\%) & 0.818 & 0.818 & 0.85 & 0.85 \\
\hline Avail. phosphorus (\%) & 0.312 & 0.312 & 0.40 & 0.40 \\
\hline SID Lysine (\%) & 0.68 & 0.68 & 1.00 & 1.00 \\
\hline SID Met. + Cist. (\%) & 0.50 & 0.50 & 0.54 & 0.54 \\
\hline SID Threonine (\%) & 0.50 & 0.50 & 0.64 & 0.64 \\
\hline SID Tryptophan (\%) & 0.15 & 0.15 & 0.19 & 0.19 \\
\hline SID Arginine (\%) & 0.97 & 0.97 & 1.02 & 1.02 \\
\hline SID Valine $(\%)$ & 0.67 & 0.67 & 0.69 & 0.69 \\
\hline Sodium $(\%)$ & 0.21 & 0.21 & 0.23 & 0.23 \\
\hline
\end{tabular}

*Mineral and vitamin mixture supplied (g/kg of diet): 10 of $\mathrm{Cu}$ (as CuSO4); 80 of $\mathrm{Fe}$ (as $\mathrm{FeSO} 4 \cdot 7 \mathrm{H}_{2} \mathrm{O}$ ); 40 of $\mathrm{Mn}($ as $\mathrm{MnO}$ ); 100 of $\mathrm{Zn}$ (as $\mathrm{ZnO}$ ); 0.6 of I (as $\mathrm{Ca}(\mathrm{IO} 3) 2) ; 0.10$ of $\mathrm{CO}$ (as $\mathrm{CoSO} 4 \cdot 7 \mathrm{H}_{2} \mathrm{O}$ ); 0.15 of $\mathrm{Se}$ (as Na2SeO3); 5,000 IU of vitamin A; 1,000 IU of vitamin D3; $15 \mathrm{IU}$ of vitamin E; $2 \mathrm{mg}$ of vitamin $\mathrm{K} 3 ; 2 \mathrm{mg}$ of thiamine; $4 \mathrm{mg}$ of riboflavin; $20 \mathrm{mg}$ of nicotinic acid; $10 \mathrm{mg}$ of d-pantothenic acid; $3 \mathrm{mg}$ of pyroxidine; $0.02 \mathrm{mg}$ of vitamin B12; $1.0 \mathrm{mg}$ of folic acid; and 0.2 $\mathrm{mg}$ of biotin. Standardized digestible AA contents were calculated from the analyzed AA content and estimated standardized digestibility coefficients from Brazilian Tables for Swine and Poultry Requirements (Rostagno, 2011). **VM = virginiamycin. Source: Authors (2018).

Following the methodology described by Barrilli et al. (2017), after birth, piglets were submitted to regular animal management procedures (i.e., tooth clipping and umbilical cord treatment). On d 3, piglets received an intramuscular injection of $200 \mathrm{mg}$ of iron dextran. If necessary, cross-fostering was realized within the first $48 \mathrm{~h}$ after birth to standardize litter size at 14 piglets. On d 10, male piglets were castrated. Piglets has access to creep feed during the entire lactation period. Supplemental heat for the piglets was provided via creep housing equipped with infrared lights during the lactation period. At weaning, sows were moved to the gestation barns and were stimulated with a mature boar twice daily to detect onset of standing estrus. Sows were inseminated when positive to the back-pressure test in the presence of the boar. During the weaning-to-estrus interval, all sows were submitted continuously to the same lactation treatments, receiving $3.0 \mathrm{~kg} \mathrm{~d}^{-1}$ of their respective lactation diet. After insemination sows had feed changed to the experimental gestation diets and were fed these diets until next lactation cycle where then they again received the lactation experimental treatments.

\subsection{Measurements and collected parameters}

Following the methodology described by Barilli et al. (2017), ambient temperature and relative humidity inside the gestation barns and lactation rooms were continuously recorded (1 measurement every $60 \mathrm{~s}$ ), using a probe (Model Log Tag 
HAXO-8, Auckland, New Zealand) installed $1 \mathrm{~m}$ above the floor. Sows were weighed 24 h post-insemination, at 84 and $110 \mathrm{~d}$ of gestation, post-farrowing and at weaning using a digital scale (Líder Balanças Ltda., Mod. LD 2000E, Araçatuba, SP, Brazil) and backfat thickness measurements were taken ultrasonically (Renco Lean-Meater, Renco Corporation, Minneapolis, USA) at $65 \mathrm{~mm}$ from the dorsal line at the last rib on each flank $24 \mathrm{~h}$ post-insemination, at 84 and $110 \mathrm{~d}$ of gestation, postfarrowing and at weaning in order to measure body weight and backfat thickness variation. Piglet and litter measurements were: total number of piglets born, born alive, stillborn, and mummies. Twenty-four hours post-farrowing and at weaning the piglets were individually weighed using a digital scale (Líder Balanças Ltda., Mod. B150, Araçatuba, SP, Brazil) in order to determine litter birth and weaning weights, and daily weight gain during lactation. All piglets that died during the lactation phase were weighed so that proper estimates of growth rates and milk production could be obtained during lactation. Every morning, feed refusals were collected from the feeding troughs (i.e., 06h30m), and fresh feed was immediately distributed once per day between $07 \mathrm{~h} 00 \mathrm{~m}$ and $08 \mathrm{~h} 00 \mathrm{~m}$. Feed consumption was calculated as the difference between offered feed and the refusals collected on the next day.

Everyday, 1 sample of feed was collected for DM content measurement, and stored at $4^{\circ} \mathrm{C}$ for further analyses. The feed samples were analyzed for DM, ash, fat content (AOAC, 1990) and CP (N $\cdot 6.25$ for feed) according to Dumas method (AOAC, 1990) and for crude fiber and for cell wall components (NDF, ADF, and ADL) according to van Soest and Wine (1967) at the Animal Nutrition Laboratory of the Universidade Federal de Minas Gerais (Montes Claros, MG, Brazil). The dietary treatments (table 1) were mash and formulated based on corn, soybean meal (45\% CP), soybean oil, and were supplemented with synthetic trace minerals, vitamins, and industrial amino acids. The ratios between digestible lysine and the essential amino acids were estimated to guarantee that they were not below that of the ideal protein ratio and to supply the nutritional requirements for gestating and lactating sows according to Rostagno (2011, table 1).

On d 18 of lactation, milk samples were collected manually from all the active mammary glands on each sow, from a pre-determined subsample of 30 sows per treatment, after an intravenous injection of 10 i.u. oxytocin into an ear vein. For that, the following protocol was applied to mimic a suckling event. Piglets were separated from the dam after suckling and 45 to $50 \mathrm{~min}$ later the sows were hand milked (Silva et al., 2009). The amount of milk collected (150 to $200 \mathrm{~mL}$ ) was close to the estimated milk production during one suckling between farrowing and d 21 . Samples were stored at $-20^{\circ} \mathrm{C}$, immediately after collection. At the end of the experiment, all samples were freeze dried and analyzed for moisture, ash, and $\mathrm{N}$ contents according to (AOAC, 1990) methods. Lactose content was measured using an enzymatic method (ENZYPLUS EZS784, BioControl Systems, Inc.). The total lipid content was determined by chloroform/methanol (2:1) according to Folch et al. (1967). Fatty acid methyl esters was prepared with $20 \%$ boron trifluoride/methanol solution according to Morrison and Smith, (1964) The fatty methyl esters were separated on a gas chromatograph equipped with a SP-2330 capillary column $(30 \mathrm{~m} \times 0.25$ $\mathrm{mm}$ internal diameter) with a non-bonded poly (80\% biscyanopropyl/20\% cyanopropylphenyl siloxane) stationary phase (a 0.20- $\mu \mathrm{m}$ film thickness). Furnace temperature was $180^{\circ} \mathrm{C}$, and injector and detector temperatures were $240^{\circ} \mathrm{C}$. The following fatty acid profiles were measured: total saturated fatty acids (Total, C16 and C18), MUFA (Total; C16:1 and C18:1) and PUFA (Total, C18:2 and C18:3).

\subsection{Calculations and Statistical Analyses}

Daily maximum, minimum, mean, and variance of daily ambient temperatures and relative humidities were averaged for each replicate and cycle. Body protein, fat, and energy contents at farrowing and at weaning were estimated according to the equations of Dourmad et al. (1997). Protein, lipid, and energy losses during lactation were estimated as the difference between calculated values determined at farrowing and at weaning. Daily milk production over the lactation period was 
calculated from litter growth rate, litter size between $\mathrm{d} 2$ and 24, and milk DM using the equation from Noblet and Etienne (1989). The effects of diet composition, replicate, parity number, and their interactions on sows and litter performance were tested according to a general linear procedure analysis of variance (GLM procedure of SAS). The effect of gestation and lactation on daily feed intake was tested with a mixed linear model (Mixed procedure of SAS) for repeated measurements with diet composition and replicate as main effects. The least square means procedure (PDIFF option) was used to compare means when a significant F-value was obtained. The number of sows returning into oestrus before and after $5 \mathrm{~d}$ post-weaning was compared using a $\chi 2$ test (Freq procedure of SAS). Milk composition data was submitted to a linear mixed model including the effect of diet and batch as main effects. In this later model, the sow was considered as a random effect and the repeated measurement option of the mixed procedure of SAS was used with an autoregressive covariance structure to take into account the correlations between repeated measurements on the same animal. Means comparison was performed according to the Pdiff option of SAS procedure using Tukey test for contrasts. Residual values were computed from the preceding models (without the random sow effect) and residual correlations between lactating performance and mean milk composition parameters were calculated using the CORR Procedure of SAS/STAT. Milk fatty acid profile was analysed using SAS GLM procedure, considering as fixed effects the cycle, treatments, parity order and possible interactions between these parameters. Least square means were compared via Tukey test and considered significant at $\mathrm{P}<0.05$.

\section{Results}

Average maximum and minimum temperatures and relative humidity levels measured during the experimental period were 32.6 and $19.8{ }^{\circ} \mathrm{C}$, and 94.1 and $46.2 \%$, respectively. A total of 9 sows (4 from control and 5 from virginiamycin treatments) were removed from the study due to low litter size at weaning (i.e., $<9$ piglets) and/or health issues. According to the experimental setup, average parity was 3.5 for the first cycle and 4.5 for the second cycle, and did not differ between treatments. No difference in gestation length nor lactation length was observed between treatments (114.5 and $22.0 \mathrm{~d}$, respectively on average).

The use of virginiamycin $(\mathrm{VM})$ during gestation tended to influence $(P=0.06)$ the total number of born and born alive when compared to control fed sows in both cycles (14.04 vs. 13.22 and 13.35 vs. 12.64, respectively; Table 2). Litter birth weight tended $(P=0.06)$ to be influenced by the use of VM in both cycles $(19.0 v s .17 .8 \mathrm{~kg}$, respectively; Table 2$)$. Sow body changes during lactation were influenced $(P=0.0001)$ by the treatments. Sows that received VM showed a lower BW loss during both lactations when compared to control sows ( $7.9 \mathrm{~kg} v s .9 .6 \mathrm{~kg}$, respectively average for both cycles; Table 2). Body protein and energy losses were also influenced by treatments, whereas sows that received VM lost less body protein mass (1.0 $\mathrm{kg} v s .1 .35 \mathrm{~kg}$, respectively average for both cycles; $P=0.001$; Table 2$)$ and energy (228 vs. $247 \mathrm{kcal}$, respectively average for both cycles; $P=0.03$; Table 2). Treatments did not influence voluntary feed intake during lactation (averaged $7.22 \mathrm{~kg} \mathrm{~d}^{-1} ; P=$ 0.918).

Litter size $(P=0.127)$ and average piglet weight $(P=0.269)$ at 48 hours were not influenced by the treatments $(13.7$ and $1.42 \mathrm{~kg}$, on average; Table 3$)$. The treatments influenced $(P=0.006)$ the litter size at weaning, it was observed that sows receiving VM weaned more piglets when compared to the control fed sows ( +0.55 piglets). There was an effect of treatment ( $P$ $=0.001)$ on piglet weaning weight, were sows from VM showed higher weights when compared to control (5.85 vs. $5.52 \mathrm{~kg}$, respectively). The litter daily gain was also influenced $(P=0.001)$ by the treatments were litters from VM fed sows showed a higher daily gain when compared to control sows (2.61 vs. $2.24 \mathrm{~kg} \mathrm{~d}^{-1}$ respectively; Table 3). Average daily milk production was $17 \%$ higher $(P=0.001)$ in the VM sows when compared with the control $\left(12.95 v s .11 .05 \mathrm{~kg} \mathrm{~d}^{-1}\right.$; Table 3$)$. The fatty acids composition of milk fat is presented in Table 4. Sows fed VM improved milk fatty acid profiles. An improvement in Paullinic acid (C20:1; $P=0.048)$, Linoleic acid $(\mathrm{C} 18: 2 ; P=0.03)$ and total PUFA (Polyunsaturated fatty acids; $P=0.03$ ) profiles were 
observed in sows fed VM when compared to control fed sows. The weaning-to-insemination interval was influenced $(P=$ 0.029; Table 2) by treatments. In both cycles the use of VM reduced the number days from weaning-to-insemination (6.4 vs. $7.4 \mathrm{~d}$ respectively for first cycle; and 6.9 vs. $7.4 \mathrm{~d}$ respectively for second cycle).

\section{Discussion}

In the present study, sows treated with VM increased productivity (higher litter size at births and weaning, fat content in milk also increased) and improved piglet and litter performance (higher piglet weight gains at birth and during lactation) over two consecutive cycles, thus confirming previous findings (Kyriakis et al., 1992; Kantas et al., 1998; Alexopoulos et al., 1998).

In our experiment sow weight gain during gestation increased in both cycles $\left(+5 \mathrm{~kg}\right.$ and $+17.4 \mathrm{~kg}$ respectively for $1^{\text {st }}$ and $2^{\text {nd }}$ ) when sows were fed VM. Similar to our findings Ilori (1984) supplementing streptomycin/ penicillin mixture and Kyriakis et al. (1992), Kantas et al. (1998) supplementing VM to sows observed that weight gain was higher during gestation when compared to control fed sows (i.e., $+19.4 \mathrm{~kg}$ on average for both cycles). The mode of action of VM consists on impacting the microbiota of the gastrointestinal tract of the pig (Dierick et al., 1986). Reducing the population of pathogenic organisms in the foregut will allow to leave the function of the hindgut bacteria essentially intact. Therefore, changes in the intestinal microbiota could have contributed to the improvement of metabolzible energy availability, also enhancing nitrogen retention via reduction of amino acid degradation and increasing the availability of essential amino acids such lysine for body growth (Dierick et al., 1986). 
Research, Society and Development, v. 10, n. 14, e363101421880, 2021

(CC BY 4.0) | ISSN 2525-3409 | DOI: http://dx.doi.org/10.33448/rsd-v10i14.21880

Table 2 - Impact of Virginiamycin on the performance of sows during gestation and lactation over two cycles (least-square means).

\begin{tabular}{|c|c|c|c|c|c|c|}
\hline \multirow[t]{2}{*}{ Parameters } & \multicolumn{2}{|c|}{ Cycle 1} & \multicolumn{2}{|c|}{ Cycle 2} & \multirow[t]{2}{*}{$\mathrm{RSD}^{1}$} & \multirow[t]{2}{*}{ Statistics $^{2}$} \\
\hline & Control & $\mathrm{VM}^{*}$ & Control & $\mathrm{VM}$ & & \\
\hline Number of sows & 76 & 75 & 76 & 75 & - & - \\
\hline Parity & 3.5 & 3.6 & 4.5 & 4.6 & - & - \\
\hline \multicolumn{7}{|l|}{ Body weight, kg } \\
\hline After insemination & 223.1 & 227.4 & 240.3 & 247.6 & 0.1 & 0.864 \\
\hline At Farrowing (net) & 252.5 & 257.5 & $243.4 \mathrm{~A}$ & $260.8 B$ & 4.2 & $0.0001(\mathrm{~T})$ \\
\hline \multicolumn{7}{|l|}{ Litter performance } \\
\hline Total number born & $13.37 \mathrm{a}$ & $14.13 b$ & $13.08 \mathrm{~A}$ & $13.95 \mathrm{~B}$ & 1.85 & $0.06(\mathrm{~T})$ \\
\hline Total number born alive & $12.77 \mathrm{a}$ & $13.35 b$ & $12.52 \mathrm{~A}$ & $13.35 \mathrm{~B}$ & 1.81 & $0.06(\mathrm{~T})$ \\
\hline Mummies & 0.18 & 0.21 & 0.19 & 0.14 & 0.67 & 0.646 \\
\hline Stillborn & 0.41 & 0.57 & 0.36 & 0.44 & 0.85 & 0.178 \\
\hline Litter weight (total born), $\mathrm{kg}$ & $18.4 \mathrm{a}$ & $19.0 \mathrm{~b}$ & $17.7 \mathrm{~A}$ & $19.7 \mathrm{~B}$ & 2.1 & $0.06(\mathrm{~T})$ \\
\hline Litter weight (born alive), $\mathrm{kg}$ & 18.2 & 18.6 & $17.5 \mathrm{~A}$ & $19.4 \mathrm{~B}$ & 2.1 & $0.08(\mathrm{~T})$ \\
\hline Piglet weight (born alive), $\mathrm{g}$ & 1442 & 1437 & 1419 & 1467 & 434 & 0.532 \\
\hline \multicolumn{7}{|l|}{ Lactation Performance } \\
\hline Sow BW loss, kg & $8.8 \mathrm{a}$ & $7.5 b$ & $10.5 \mathrm{~A}$ & $8.1 \mathrm{~B}$ & 1.3 & $0.0001(\mathrm{~T}, \mathrm{C})$ \\
\hline Sow BW loss, $\%$ & $3.5 \mathrm{a}$ & $2.9 \mathrm{~b}$ & $4.3 \mathrm{~A}$ & $3.2 \mathrm{~B}$ & 0.8 & $0.0001(\mathrm{~T}, \mathrm{C})$ \\
\hline Protein loss, $\mathrm{kg}$ & $1.2 \mathrm{a}$ & $1.0 \mathrm{~b}$ & $1.5 \mathrm{~A}$ & $1.1 \mathrm{~B}$ & 0.8 & $0.001(\mathrm{~T}, \mathrm{C})$ \\
\hline Lipid loss, kg & 5.0 & 4.7 & 5.3 & 5.1 & 1.5 & 0.815 \\
\hline Energy loss, Kcal & $237 \mathrm{a}$ & $220 b$ & 257A & 237B & 9.0 & $0.03(\mathrm{~T}, \mathrm{C})$ \\
\hline Lactation $\mathrm{ADFI}^{* *}, \mathrm{~kg} \mathrm{~d}^{-1}$ & 7.35 & 7.31 & 7.09 & 7.25 & 0.8 & 0.918 \\
\hline Interval weaning to insemination, $\mathrm{d}$ & $8.0 \mathrm{a}$ & $6.4 \mathrm{~b}$ & $7.4 \mathrm{~A}$ & $6.9 \mathrm{~B}$ & 2.4 & $0.029(\mathrm{~T})$ \\
\hline
\end{tabular}

${ }^{1} \mathrm{RSD}=$ residual standard deviation. ${ }^{2}$ Obtained by analysis of variance $(\mathrm{GLM}$ including the effects of treatment $(\mathrm{T})$, cycle $(\mathrm{C}))$. $* \mathrm{VM}=$ virginiamycin. $* * \mathrm{ADFI}=$ average daily feed intake. Source: Authors (2018). 
Research, Society and Development, v. 10, n. 14, e363101421880, 2021

(CC BY 4.0) | ISSN 2525-3409 | DOI: http://dx.doi.org/10.33448/rsd-v10i14.21880

Table 3 - Impact of Virginiamycin on the performance of litters during lactation over two cycles (least-square means).

\begin{tabular}{|c|c|c|c|c|c|c|}
\hline \multirow[t]{2}{*}{ Parameters } & \multicolumn{2}{|c|}{ Cycle 1} & \multicolumn{2}{|c|}{ Cycle 2} & \multirow{2}{*}{$\mathrm{RSD}^{1}$} & \multirow[t]{2}{*}{ Statistics $^{3}$} \\
\hline & Control & $\mathrm{VM}^{*}$ & Control & VM & & \\
\hline Lactation, $\mathrm{d}$ & 21.6 & 21.7 & 22.0 & 21.9 & 1.5 & 0.254 \\
\hline \multicolumn{7}{|l|}{ Litter size } \\
\hline At 48 hours & 13.9 & 13.8 & 13.9 & 13.5 & 0.8 & 0.127 \\
\hline At weaning & $11.9 \mathrm{a}$ & $12.4 \mathrm{~b}$ & $12.1 \mathrm{~A}$ & $12.7 \mathrm{~B}$ & 1.2 & $0.006(\mathrm{~T})$ \\
\hline \multicolumn{7}{|l|}{ Piglet average weight, $\mathrm{kg}$} \\
\hline At 48 hours & 1.376 & 1.378 & 1.435 & 1.488 & 0.36 & 0.269 \\
\hline At weaning & $5.50 \mathrm{a}$ & $5.97 b$ & $5.54 \mathrm{~A}$ & $5.73 \mathrm{~B}$ & 0.85 & $0.0001(\mathrm{~T})$ \\
\hline \multicolumn{7}{|l|}{ Litter average weight, $\mathrm{kg}$} \\
\hline At 48 hours & 19.2 & 19.1 & 19.9 & 20.1 & 1.4 & 0.738 \\
\hline At weaning & $65.5 \mathrm{a}$ & $74.0 \mathrm{~b}$ & $67.4 \mathrm{~A}$ & $72.5 \mathrm{~B}$ & 3.3 & $0.0001(\mathrm{~T})$ \\
\hline Piglet weight gain, $\mathrm{g} \mathrm{d}^{-1}$ & $211 \mathrm{a}$ & $235 b$ & $180 \mathrm{~A}$ & 195B & 187 & $0.0001(\mathrm{~T}, \mathrm{C})$ \\
\hline Litter weight gain, $\mathrm{kg} \mathrm{d}^{-1}$ & $2.40 \mathrm{a}$ & $2.82 b$ & $2.09 \mathrm{~A}$ & $2.40 \mathrm{~B}$ & 0.73 & $0.0001(\mathrm{~T})$ \\
\hline Milk production ${ }^{2}, \mathrm{~kg} \mathrm{~d}^{-1}$ & $11.8 \mathrm{a}$ & $14.0 \mathrm{~b}$ & $10.3 \mathrm{~A}$ & $11.9 \mathrm{~B}$ & 1.7 & $0.001(\mathrm{~T}, \mathrm{C})$ \\
\hline
\end{tabular}

${ }^{1} \mathrm{RSD}=$ residual standard deviation.

${ }^{2}$ Daily milk production calculated considering litter weight gain (DWG), litter size, and milk dry matter content (19\%) applied to the equation of Noblet and Etienne (1989). MP $(\mathrm{kg} / \mathrm{d})=([0.718 \times \mathrm{DWG}-4.9] \times \mathrm{n}$. piglets $) / 0.19$.

${ }^{3}$ Obtained by analysis of variance (GLM including the effects of treatment (T) and cycle (C).

*VM = virginiamycin.

Source: Authors (2018). 
In our study sows treated during gestation with VM during both cycles increased the number of total born $(+0.76$ and +0.87 piglets, respectively for $1^{\text {st }}$ and $\left.2^{\text {nd }}\right)$ and born alive $\left(+0.58\right.$ and +0.83 piglets, respectively for $1^{\text {st }}$ and $\left.2^{\text {nd }}\right)$. In agreement with our results, Hsu et al. (1980) feeding lincomycin and Kyriakis et al. (1992), Kantas et al. (1998) feeding VM to gestating sows also reported an increased number of piglets born alive (i.e., +0.99 piglets, on average for two cycles). Controversially to our findings, Monetti et al. (1998) supplementing sows with 40 ppm VM during two consecutive cycles did not find effects on sow productivity nor piglet performance. According the later authors, the lack of clear results in comparison to previous studies could have been due to the higher variability of the sows that were randomly assigned to their trial. Still in a similar way to the later authors, Frolich et al. (1974) evaluating the effects of seven different antibiotics, including VM, stated that there was no justification for feeding antibiotics to sows for short treatment periods (i.e., 7 wks.), being justifiable only for longer durations.

Table 4 - Impact of Virginiamycin on milk fatty acid profile of sows on d 18 of lactation over two cycles (least-square means).

\begin{tabular}{|c|c|c|c|c|c|c|c|}
\hline \multirow{2}{*}{ Treatments/ Cycle } & \multicolumn{2}{|c|}{ Control } & \multicolumn{2}{|c|}{$\mathrm{VM}^{*}$} & \multicolumn{3}{|c|}{ Statistics $^{2}$} \\
\hline & 1 & 2 & 1 & 2 & \multirow{2}{*}{$\mathrm{RSD}^{1}$} & \multirow{2}{*}{$\mathrm{C}$} & \multirow{2}{*}{$\mathrm{T}$} \\
\hline Number of sows & 31 & 25 & 29 & 28 & & & \\
\hline \multicolumn{8}{|l|}{ Saturated FA, \% } \\
\hline C12:0 & 0.26 & 0.36 & 0.25 & 0.36 & 0.07 & 0.0001 & 0.259 \\
\hline C14:0 & 3.23 & 3.74 & 3.09 & 3.92 & 0.12 & 0.0001 & 0.419 \\
\hline $\mathrm{C} 15: 0$ & 0.10 & 0.10 & 0.12 & 0.12 & 0.03 & 0.0424 & 0.434 \\
\hline $\mathrm{C} 16: 0$ & 31.36 & 32.92 & 30.38 & 34.51 & 0.36 & 0.0037 & 0.167 \\
\hline C18:0 & 3.46 & 3.66 & 3.38 & 3.54 & 0.01 & 0.0001 & 0.860 \\
\hline C20:0 & 0.06 & 0.07 & 0.06 & 0.07 & 0.01 & 0.0208 & 0.715 \\
\hline Total Saturated FA & 39.24 & 42.51 & 37.86 & 43.43 & 10.60 & 0.001 & 0.871 \\
\hline \multicolumn{8}{|l|}{ Monounsaturated FA, \% } \\
\hline $\mathrm{C} 14: 1$ & 0.25 & 0.34 & 0.22 & 0.34 & 0.01 & 0.0002 & 0.452 \\
\hline C16:1 & 8.96 & 11.99 & 8.45 & 12.29 & 0.00 & 0.0002 & 0.608 \\
\hline C18:1 & 23.60 & 27.50 & 23.43 & 27.63 & 0.72 & 0.0001 & 0.506 \\
\hline $\mathrm{C} 20: 1$ & $0.41 \mathrm{~A}$ & $0.17 \mathrm{a}$ & $0.45 \mathrm{~B}$ & $0.19 b$ & 0.01 & 0.0006 & 0.040 \\
\hline Total MUFA & 38.97 & 42.67 & 38.10 & 42.96 & 6.87 & 0.0001 & 0.607 \\
\hline \multicolumn{8}{|l|}{ Polyunsaturated FA, \% } \\
\hline C18:2 & $17.84 \mathrm{~A}$ & $11.13 \mathrm{a}$ & $20.11 B$ & $11.04 \mathrm{~b}$ & 0.69 & 0.0001 & 0.030 \\
\hline $\mathrm{C} 18: 3$ & $0.89 \mathrm{~A}$ & $0.53 \mathrm{a}$ & $1.06 \mathrm{~B}$ & $0.48 b$ & 0.01 & 0.0001 & 0.080 \\
\hline $\mathrm{C} 20: 2$ & 0.14 & 0.15 & 0.14 & 0.14 & 0.01 & 0.0001 & 0.439 \\
\hline C20:4 & 0.33 & 0.42 & 0.32 & 0.42 & 0.00 & 0.0001 & 0.241 \\
\hline Total PUFA & $19.33 \mathrm{~A}$ & $12.10 \mathrm{a}$ & $21.75 \mathrm{~B}$ & $12.38 \mathrm{~b}$ & 8.18 & 0.0001 & 0.030 \\
\hline
\end{tabular}

${ }^{1} \mathrm{RSD}=$ residual standard deviation. ${ }^{2}$ Obtained by analysis of variance (including the effects of cycle (C) and treatment (T)). $* \mathrm{VM}=$ virginiamycin. Source: Authors (2018).

Treatments did not influence sow voluntary feed intake during lactation in both cycles. Nevertheless, significant improvements were observed for average daily litter weight gain (i.e., $+16 \%$ on average for both cycles), average weaning weight of piglets (i.e., $+6 \%$ on average for both cycles) and litters (i.e., $+11 \%$ on average for both cycles) and number of weaned piglets (i.e., +0.55 piglets on average for both cycles) for the sows fed the VM. Several studies (Mayrose et al., 1962; Hsu et al., 1980; Haydon \& Hale, 1988; Kyriakis et al., 1992; Kantas et al., 1998) testing different antibiotics added to the feed of the sow during lactation phase have indicated improvements in piglet and litter weight gain and higher number of weaned piglets. This improvement in litter and piglet performance could be related to reduction of pathogen pressure and/ or to the fact that the piglets benefitted from the increased milk yield and higher milk fatty acid profile of the sows fed VM. Gram-positive bacteria such as Clostridium difficile, that represent a risk to neonatal piglets and are present via environmental spores originated from the sows (Lobato et al., 2013), can also be controlled with the use of VM in the diet. As the metabolism of 
specific Gram-positive bacteria in the foregut can be inhibited by the use of VM, an increased absorption of nutrients such as: glucose, proteins and amino acids in the small intestine can be expected, improving nutrient efficiency utilization for milk synthesis (Henderickx et al., 1981).

Sows receiving VM showed a higher daily milk production during both cycles (i.e., $+17 \%$ on average for both cycles). With reference to milk production, the impact of antibiotics on this trait has been shown in several papers. Using VM, Kyriakis et al. (1992) reported that the supplementation during lactation enhanced milk yield and milk composition. In a similar way using lasalocid, Kadamanova (1984) and Haydon and Hale (1988) obtained improvements in milk production. The increase in milk yield observed across all studies could be due to the beneficial impact of reducing the impacts of detrimental microbiota and therefore, with less pathogen pressure improving metabolizible energy and amino acid availability for milk synthesis. Our hypothesis is confirmed by Kyriakis et al. (1992) that stated that the enhancement of the nutritional efficiency from using VM is mainly related to a change in the metabolic activity and efficiency of the gut microbiota, improving amino acid availability and leading to a reduced energy wastage.

Our findings are in agreement with results previously published in the literature, where more than $80 \%$ of the fatty acids in sow's milk fat is composed by palmitic (16:0), oleic (18:1) and linoleic acids (18:2) (Miller et al., 1971; Csapó et al., 1996; Gerfault et al., 1999; Silva et al., 2017). In our study, the improved growth rates of the piglets until weaning, are not only related to a higher sow milk yield, but also to an increased energy content of the milk.

According to Darragh and Moughan (1988) and Silva et al. (2017) blood triacylglycerol reflect closely most of the fatty acids found in milk, which are influenced by the dietary type of fat ingested by the sow and/or the amount of fat tissue mobilized by the sow. Nutrients such as glucose that are not absorbed in the small intestine can be fermented in the caecum and the large intestine, having as end products volatile fatty acids, which can be absorbed and redirected towards milk fatty acid synthesis. However, according to Alexopoulos et al. (1998), the use of VM does not influence the microbiota which acts on fermentation of fibre to soluble volatile fatty acids in the hindgut. Therefore, our findings regarding improvements in milk fatty acid composition could be related to a nutrient-sparing effect on energy utilization (Kyriakis et al., 1992; Kantas et al., 1998; Alexopoulos et al., 1998). Moreover, our findings indicated that the continuous use of VM throughout two consecutive parities significantly improved milk quality of sows by increasing milk C18:2, C20:1 and total PUFA content. Similar to our findings, Alexopoulos et al. (1998), Haydon ad Hale (1988), Kyriakis et al. (1992) observed significant variations in milk fatty acid composition over more than one parity. Data from the previous studies and from our research indicate that the continuous use of VM in the diet has constantly positive effects on sow's milk quality. In our study the VM treated sows showed weaningto-insemination intervals always lower than control fed sows in both cycles. Similar to our findings, Monetti et al. (1998) and Kantas et al. (1998) also reported reduced weaning-to-estrus and weaning-to-conception intervals for sows that received VM. According to the later authors, this improvement in reproductive performance could be related to improvement of the health status promoted by the use of VM and/ or to the increase of weight condition and more specifically to the reduction of body weight loss during the lactation period.

\section{Conclusion}

In conclusion, our study demonstrates that the constant use of VM in the diets of sows during both gestation and lactation improves both sow and litter performance. Our results confirm that the sow can increase productivity and remain in ideal body conditions for the next parity. The higher the longevity, the more productive the sow is, this being of beneficial importance to commercial pig producers. Furthermore, additional studies are necessary to better understand the impacts of different feed additives on productive and reproductive performance of modern high producing sows. 


\section{Acknowledgements}

This work was supported by Phibro Animal Health Corporation (07.112-070, Av. Pres. Tancredo de Almeida Neves 1063, Guarulhos, São Paulo, Brazil). The authors gratefully acknowledge the farm owner (Grupo Cabo Verde) for the opportunity of performing this study in their pig facilities; and also, gratefully acknowledge the technician Maria Antonia Ladalardo Etchegaray from the ESALQ-USP Nutrition and Animal Growth Laboratory for her support and dedication in running all milk fatty acid profile analyses.

\section{References}

AOAC- The Association of Official Analytical Chemists. (1990) Official Methods of Analysis. (15th ed.), P1106.

Alexopoulos, C., Tsinas, A., Kantas, D., Florou-Paneri, P., Read, M. P., Vassilopoulos, V., \& Kyriakis, S. C. (1998). Dose titration study on the effect of virginiamycin on specific blood parameters and milk quality in the sow. Journal of Veterinary Medical Archives.45(9), 535-542.

Barrili, L. E. N., Silva, B.A.N., Maiorka, A., Falleiros, F. T., Silva, C. C., Raidan, F. S., \& Araujo, W.A.G. (2017). Evaluation of Different Calcium Sources on the Performance of Highly Prolific Lactating Sows. Journal of Veterinary Science \& Technology, 8(3), 438-444.

Curran, M., Lean, I., Edge, M., Hawkey-Smith, C., \& Read, M. P. (1994). The effect of virginiamycin on sow and litter performance. Journal of Animal Science, 55(3), 123-132.

Csapó, J., Martin, T. G., Csapó-kiss, Z. S., \& Hjzas, Z. (1996). Protein, fats, vitamin and mineral concentrations in porcine colostrum and milk from parturition to 60 days. International Dairy Journal 6(8-9), 881-902.

Darragh, A. J., \& Moughan, P. J. (1988). Composition of sow' colostrum and milk. In: Verstegen M. W., Moughan P. J., \& Schrama J. W. (Eds.), The Lactating Sow. Wageningen Pers, Wageningen,1-19.

Dierick, J. A., Vervaeke, I. J., Decuypere, J. A., \& Henderickx, H. K. (1986). Influence of the gut flora and of some growth-promoting feed additives on nitrogen metabolism in pigs. II. Studies in vivo. Livestock Production Science 14(2), 161-176.

Dourmad, J. Y., Etienne, M., Noblet, J., \& Causeur, D. (1997). Prediction of the chemical composition of breeding sows from live weight and back fat thickness. Journees de la Recherche Porcine, 29, 255-262.

Folch, J., Lee, M., \& Sloane-Stanley, G. H. (1967). A simple method for the isolation and purification of total lipids from animals' tissues. Journal of Biological Chemistry, 497-509.

Frohlich, A., Kvarnfos, E., Mansson, I., \& Simonsson, A. (1974). Antibiotic additives in sows' diets: Effects on production and intestinal flora. Acta Agriculturae Scandinavica 24(3), 273-285.

Gerfault, V., Mourot, J., Etienne, M., \& Mounier, A. (1999). Influence of the source of lipids added to the sow pregnancy diet on reproductive performance and on body composition of piglets at birth. Journées de la Recherche Porcine en France 31, 191-197.

Haydon, K. D., \& Hale, O. M. (1988). Effect of lasalocid on reproductive performance and subsequent lactation in the sow. Journal of Animal Science 66(8), $1877-1884$.

Hsu, F. S., Chen, H. W., Wung, S. C., Luchsinger, J. H., \& Fang, W. S. (1980). Effects of lincomycin on reproductive performance of sows. Journal of the Chinese Society of Veterinary Science 6(2), 71-76.

Ilori, J. O. (1984). The effect of different proportions of protein and antibiotic in the diet on reproductive performance of indigenous pigs in Nigeria. Journal of Agricultural Science, Cambridge 102(1), 227-232.

Kadamanova, L. D. (1984). Increased litter size and litter weight from sows given bacitracin. Sbornik Nauchnykn Trudov Byelorusskoi Sel'skokhozyaistvennoi Akademii 118, 28-32.

Kantas, D., Vassilopoulos, V., Kyriakis, S. C., \& Saoulidis, K. (1998). Dose titration study on the effect of virginiamycin on gilt/ sow and piglet performance. Journal of Veterinary Medical Archives 45(1-10), 525-533.

Kim, S. W., Hurley, W. L., Wu, G., \& Ji, F. (2009). Ideal amino acid balance for sows during gestation and lactation. Journal of Animal Science 87(14), 123132.

Kyriakis, S. C., Vassilopoulos, V., Demade, I., Kissels, W., Polizopoulou, Z., \& Milner, C. K. (1992). The effect of virgniamycin on sow and litter performance. Animal Production 55(3), 431-436.

Lobato, F. C. F., Salvarani, F. M., Gonçalves, L. A., Pires, P. S., Silva, R. O. S., Alves, G. G., Neves, M. S., Junior, C. A. O., \& Pereira, P. L. L. (2013) Clostridioses in farm animals. Veterinária e Zootecnia 20, 29- 48.

Mayrose, V. B., Speer, V. C., McCall, J. T., \& Hays, V. W. (1962). Effect of an antibiotic and protein source on swine reproduction. Journal of Animal Science. 21, 1005. 
Research, Society and Development, v. 10, n. 14, e363101421880, 2021

(CC BY 4.0) | ISSN 2525-3409 | DOI: http://dx.doi.org/10.33448/rsd-v10i14.21880

Miller, G. M., Conrad, J. H., \& Harrington, R. B. (1971). Effect of Dietary Unsaturated Fatty Acids and Stage of Lactation on Milk Composition and Adipose Tissue in Swine. Journal Animal Science 32(1), 79-83.

Monetti, P. G., Tassinari, M., Vignola, G., Maculan, L., \& Read, M. P. (1998). The effect of virginiamycin supplementation in sow diets on the reproductive performance of the gilt/ sow. Animal Science 66(1), 231-238.

Morrison, W. R., \& Smith, L. M. (1964). Preparation of fatty acid methyl esters and dimethylacetals from lipids with boron fluoride methanol. Journal of Lipid Research 5(4), 600-608.

Noblet, J., \& Etienne, M. (1989). Estimation of sow milk nutrient output. Journal of Animal Science 67(12), 3352-3359.

Quiniou, N., \& Noblet, J. (1999). Influence of high ambient temperatures on performance of multiparous lactating sows. Journal Animal Science 77(8), 21242134

Rostagno, H. S. (2011). Brazilian tables for poultry and swine: composition of feedstuffs and nutritional requirements. Editor Horácio Santiago Rostagno, translated by Bettina Gertum Becker, 3rd Ed, Press Universidade Federal de Viçosa (UFV), Viçosa, Brazil. P251.

Silva, B. A. N., Noblet, J., Donzele, J. L., Oliveira, R. F. M., Primot, Y., Gourdine, J. L., \& Renaudeau, D. (2009). Effects of dietary protein level and amino acid supplementation on performance of mixed-parity lactating sows in a tropical humid climate. Journal of Animal Science 87(12), 4003-4012.

Silva, B. A. N., Gourdine, J. L., Corrent, E., Primot, Y., Mourot, J., Noblet, J., \& Renaudeau, D. (2017). Effects of Dietary Protein Content on Milk Composition of Mixed Parity Lactating Sows in a Tropical Humid Climate. Journal of Veterinary Science and Technology 8(4), 446-453.

Van Soest, P. J., \& Wine, R. H. (1967). Use of detergents in the analysis of fibrous feeds. IV. Determination of plant cell-wall constituents. Journal of The Association of Official Analytical Chemists 50: 50-55. 